\title{
Temperature Control of a Small Volume-Thermal System in Heating and Cooling Processes with Arduino
}

\author{
Atilla BAYRAM*, Sulaiman Abdullah MOHAMMED \\ Van Yuzuncu Yil University, Mechanical Engineering Department, Van \\ (ORCID: 0000-0002-0071-2206)(ORCID: 0000-0002-1662-9976)
}

\begin{abstract}
$\ddot{O} \mathbf{z}$
Sıcaklık kontrolünün önemli bir uygulama alanı malzemelerin mekanik karakteristiklerinin tanımlanmasındaki kullanımıdır. Bu çalışmada sıcaklık kontrollü bir ısıtma ve soğutma sisteminin tasarımı sunulmaktadır. Çok geniş̧ sıcaklık aralıklarında çalışmaya izin veren bu sistem bir çekme-basma test cihazı için tasarlanmıştır. Çekmebasma deneylerinin yapıldığı haznenin sıcaklığı testler sırasında istenilen sıcaklık aralıklarında tutulması amaçlanmıştır. Bu termal sistem yalıtılmış metal hazne, kuru rezistans, güç ayarlayıcı, 1sıl çift, hava fanı, röle, yükseltici, mikro kontrolcü ve bilgisayar gibi temel elektrik ve mekanik elemanlardan oluşmaktadır. Krojenik sıcaklıklarda soğutma işlemi için ise bu elemanlara ek olarak solenoid valf, DC motor sürücü ve sıvı azot tankı sisteme eklenmiştir. Haznenin içinin sıcaklığı geri beslemeli bir sistem ile kontrol edilmektedir. Bu geri beslemeli kontrol sistemi sıcaklığı bir K-tipi ısıl çift ile ölçmekte olup hataları telafi etmek için tablo destekli PID, P ve onoff kontrolcülerin bir kombinasyonu kullanılmaktadır. Soğutma kısmında ise sıcaklık kontrolü valf karakteristiğine uygun olarak oransal kontrol işlemi ile yapılmaktadır. Bu sitemde basit, ucuz ve programlanması kolay olduğu için mikro kontrolcü olarak Arduino işlemci kartı kullanılmıştır. Bilgisayar ve deney düzeneği arasındaki tüm haberleşmeler bu kart aracıllğı ile gerçekleştirilmiş̧ir. Gerçek zamanlı uygulamalar için MATLAB programı üzerinde yazılan programlar hem haberleşmede hem de kontrolde büyük bir başarı göstermiş̧tir. Bu çalışmada, yalıtılmış haznenin sıcaklığı $+450{ }^{\circ} \mathrm{C}$ ila $-100{ }^{\circ} \mathrm{C}$ arasında kolay bir şekilde tutulabilmiştir. Bazı deneysel çalışmaların uygulanmasıyla, kullanıcı tanımlı değişik sıcaklık profilleri başarılı bir şekilde test cihazı üzerinde gerçekleştirilmiş ve sonuçlar ssıtma ve soğutma sisteminin matematiksel modelinden elde edilen sonuçlar ile karşılaştırılmıştır. Oluşan sapmaların çekme-basma test cihazı uygulaması için kabul edilebilir bir seviyede oldukları görülmüştür.
\end{abstract}

Anahtar kelimeler: Sicaklık kontrol sistemi, Isıtma, Soğutma, Arduino.

\section{Temperature Control of a Small Volume-Thermal System in Heating and Cooling Processes with Arduino}

\section{Abstract}

An important field of the temperature control is the identification of physical features of materials at a wide range of operating temperatures. This paper presents the design of a temperature controlled thermal system in heating and cooling processes. This system will be used in a tension-compression testing machine. During the tensile experiments, the aim is to keep the inside of the chamber at a desired temperature. The thermal system consists of an isolated metal box, dry resistance, power regulator, thermocouple, air fun, relay, amplifier, microcontroller and computer. For the cooling processes in cryogenic temperatures, the system has also a solenoid valve, DC motor driver and a liquid nitrogen tank. The temperature of the chamber with a small bulk is controlled by a feedback system. This feedback system measures the temperature with a K-type thermocouple and uses a combination of a table-supported PID, $\mathrm{P}$ and on-off controllers to compensate the errors between the reference and measured temperatures. In this setup, Arduino is used as a microcontroller because it is simple, inexpensive and easy to program. This card supplies all communication between the computer and the experimental setup by a program written on MATLAB with Arduino package for real-time applications. According to the experimental results, the temperature of the insulated chamber can be easily maintained between $+450{ }^{\circ} \mathrm{C}$ and $-100{ }^{\circ} \mathrm{C}$. The user defined different temperature profiles were successfully performed on the setup and the outcomes were compared with the
\end{abstract}

\footnotetext{
*Sorumlu yazar: atillabayram@yyu.edu.tr

Geliş Tarihi: 22.02.2019, Kabul Tarihi: 01.07.2019
} 
mathematical model in the heating and cooling processes. The deviations from the desired temperatures were found to be at an acceptable level for the applications on a tension-compression testing machine.

Keywords: Temperature control system, Heating, Cooling, Arduino.

\section{Introduction}

Temperature control has an important role in daily life, especially in industrial applications including production areas such as food, chemistry and mechanical processes. Another specific area of the temperature control is the scientific studies in laboratory. In general, metal materials have a wide range of applications under different working conditions, in particular, thermal conditions. As known, the materials have different mechanical, electrical, chemical and thermal characteristics under different temperatures in heating and cooling processes. So as to select the proper materials to be used in design, the characteristics of the materials must be defined under some variable conditions. In addition to the heating process, the cooling process can also change the features of materials. Obtaining specific mechanical properties of a metallic material such as hardness, strength, flexibility and reduction of residual stresses is achieved by a successful heat treatment. Many heat treatment processes require accurate temperature control over the heating or cooling cycles. In some cases, industrial processes or environments in which the materials are used are exposed to extremely high temperatures (exceeding $400{ }^{\circ} \mathrm{C}$ ). On the other hand, in some areas like the wings of high-flying aircraft, the temperature may drop to cryogenic temperatures of approximately $-70{ }^{\circ} \mathrm{C}$. In these conditions, metal or other materials are subjected to overstress and distortion during the operation. The same conditions in laboratory environment are simulated by heating and cooling at different temperature profiles.

In literature, the control of heating and/or cooling of the systems is given in several studies with different approaches. Generally, these studies are about temperature control of buildings and various industrial processes [1-3]. They are based on heat and mass transfer and involve the modeling and controls in narrow ranges approximately at ambient temperature. On the other hand, some studies on heating applications with higher operating temperatures such as ovens and industrial furnaces are also found in literature. Haye was working on industrial solutions for induction heating of steels [4] while Ryckaert et al. published an article on the improvement of the performance of an oven using advanced control algorithms [5]. In another study, the researchers also worked on an electromagnetic cooker to be used as a solution in electronic production processes for melting steels [6].

Refrigerators or cold storage houses come to mind when generally to say the cooling process. However, the number of studies on the operations at temperatures of $-100{ }^{\circ} \mathrm{C}$ or lower called cryogenic is limited. To achieve this low temperature values, the liquefied gases are utilized. Among these gases, the most commonly used is liquefied nitrogen. Dhananchezian, et al. investigated experimentally cryogenic cooling in the vertical cutting by using the liquid nitrogen jet [7]. According to the experimental results of this study, it is stated that cutting temperature is reduced by $19-40 \%$, maximum shear force $10-15 \%$ and chip thickness $25 \%$ compared to dry cutting process. In another study, the large infra-red device is pre-cooled with liquid nitrogen to keep the infrared device safe [8].

Temperature control in industrial processes and heat treatment is very important for system performance and cost of production. Many studies have been conducted on this subject. In one of these studies, an automatic controller has been designed and developed for drying ovens [9]. In this system with PIC18F4220 microcontroller, the control action is performed automatically by measuring the temperature with a K-type thermocouple. In another study, Appelblad developed a temperature control cell for Raman spectroscopy, which is used to detect gases on-site utilizing an Arduino Uno microprocessor with a proportional + integral (PI) control [10]. It is expressed that the temperature of a surface oxidized by this spectroscopy can be normalized by the controlled cell between $-15^{\circ} \mathrm{C}$ and +110 ${ }^{\circ} \mathrm{C}$, and the set point temperature of $\pm 0.22{ }^{\circ} \mathrm{C}$ is able to be kept constant for a long time. This system is also used for cooling or heating according to the set point.

In literature, the temperature control process is generally implemented by some classical controllers such as PID, On-Off as well as more modern controllers such as Fuzzy-Logic, artificial neural networks. Each method is used for a specific process related to industrial needs which are high accuracy, robustness and response speed. A model reference adaptive control method with a PI controller was presented for an electro-magnetic furnace [6] while a predictive control system were able 
to control the internal temperature of an experimental cell at the desired limits based on the model estimation for almost the entire working time[11]. In another study on controller design, a new type of self-regulating Fuzzy controller was applied on temperature control unit and it is stated that a control system with superior performance was obtained compared to classical PID [12].

In temperature control systems, PLC (Programmable Logic Controller) is widely preferred in industry as a microprocessor. Ding and Li conducted a study on PLC as an industrial control unit [13]. They stated that this system was a stable, highly reliable, economically reasonable and had wide application field in control applications. In addition to PLC, the temperature control of an oven was performed with PIC microcontroller on MATLAB-SIMULINK [14]. The communication between the oven and the computer is provided via a PIC microprocessor through RS-232. As a new trend, Arduino microprocessors, which are relatively inexpensive, easy to use and easy to program, have been used in many control systems as well as in temperature control. Krishnamurthi, et al. used Arduino to measure the real-time air-conditioning such as humidity and temperature [15] while Ayuba designed the temperature control system in a factory with Arduino [16]. In this study, the cooling unit was activated automatically as ON when the temperature reading by the sensor which interfaces with the Arduino was higher than the desired temperature of the factory. This provided a possibility to adjust the cooling speed unit.

This study involves the design of a temperature controlled system in heating and cooling process to be used on a tension-compression testing machine. The heating side of this system, which operates in very wide ranges of temperature, is mainly composed of an insulated metal box, dry resistance, power regulator, thermocouple, air fan, relay, amplifier, microcontroller and computer. In addition to these components, the cooling unit involves a solenoid valve, DC motor driver and liquid nitrogen tank. The temperature of the inner part of the chamber is controlled by the table-supported PID controller based on many experimental results involving the temperature rates and applied control voltages. On the cooling side, the feedback action is generated by a proportional controller according to the valve characteristic. In this experimental study, the heating and cooling processes can be carried out separately or simultaneously. In heating process, PWM (Pulse With Modulation) between 0-5 DCV from Arduino could adjust the $220 \mathrm{~V}$ AC voltage via power regulator for several reference temperatures. In cooling process, a constant DC voltage for the calculated time proportional to the temperature error was applied to the solenoid valve for tuning the amount of liquid nitrogen. All programs for controlling and communication have been written on MATLAB environment. In the experiments, it was observed that the thermal system presented in this study generated any user-defined temperature profiles to be tracked approximately over $+450{ }^{\circ} \mathrm{C}$ and the cryogenic temperatures of lower than $-100{ }^{\circ} \mathrm{C}$. Although there have been errors due to the system structure and the capability of the equipments used in the setup, these temperature deviations have been seen to be acceptable level for the tension-compression testing machine.

\section{Material and Method}

\subsection{The Setup Design for Heating and Cooling Processes}

The main purpose of this study is to control the temperature of a thermal system by heating up to the high temperatures of $+450{ }^{\circ} \mathrm{C}$ and cooling down to the cryogenic temperatures of $-100{ }^{\circ} \mathrm{C}$ using some electrical-electronic and mechanical apparatus. The schematic representation of the system given in Figure 1 can be examined under two main topics which are heating and cooling units. These parts can be operated separately or simultaneously. The heating unit consists of an insulated box, dry resistance, and power regulator while the cooling side involves a solenoid valve, DC motor drive, fan and liquid nitrogen tank. In addition, K-type thermocouples, amplifiers, microprocessor card and a computer are also included to the system as measuring and microprocessor elements for both processes.

The insulated chamber was manufactured by placing rock wool $(7 \mathrm{~cm})$ between two steel plates ( $3 \mathrm{~mm}$ each) with outer dimensions $(0.4 \mathrm{~m} \times 0.4 \mathrm{~m} \mathrm{x} 0.4 \mathrm{M})$ and inner dimensions $(0.25 \mathrm{~m} \mathrm{x} 0.25 \mathrm{~m} \mathrm{x}$ $0.25 \mathrm{~m}$ ). The capacity of the dry resistor is $2.5 \mathrm{~kW}$ and this power can be regulated from 0 to $2.5 \mathrm{~kW}$ depending on the desired heat load for the required temperature. The power regulator from ELKON can achieve the variable voltage for $0-220 \mathrm{~V}$ AC. This adjustment is carried out by applying PWM signals between 0-5 VDC via Arduino board known as a microcontroller. In other words, PWM can generate 
the trigger input to the power regulator.

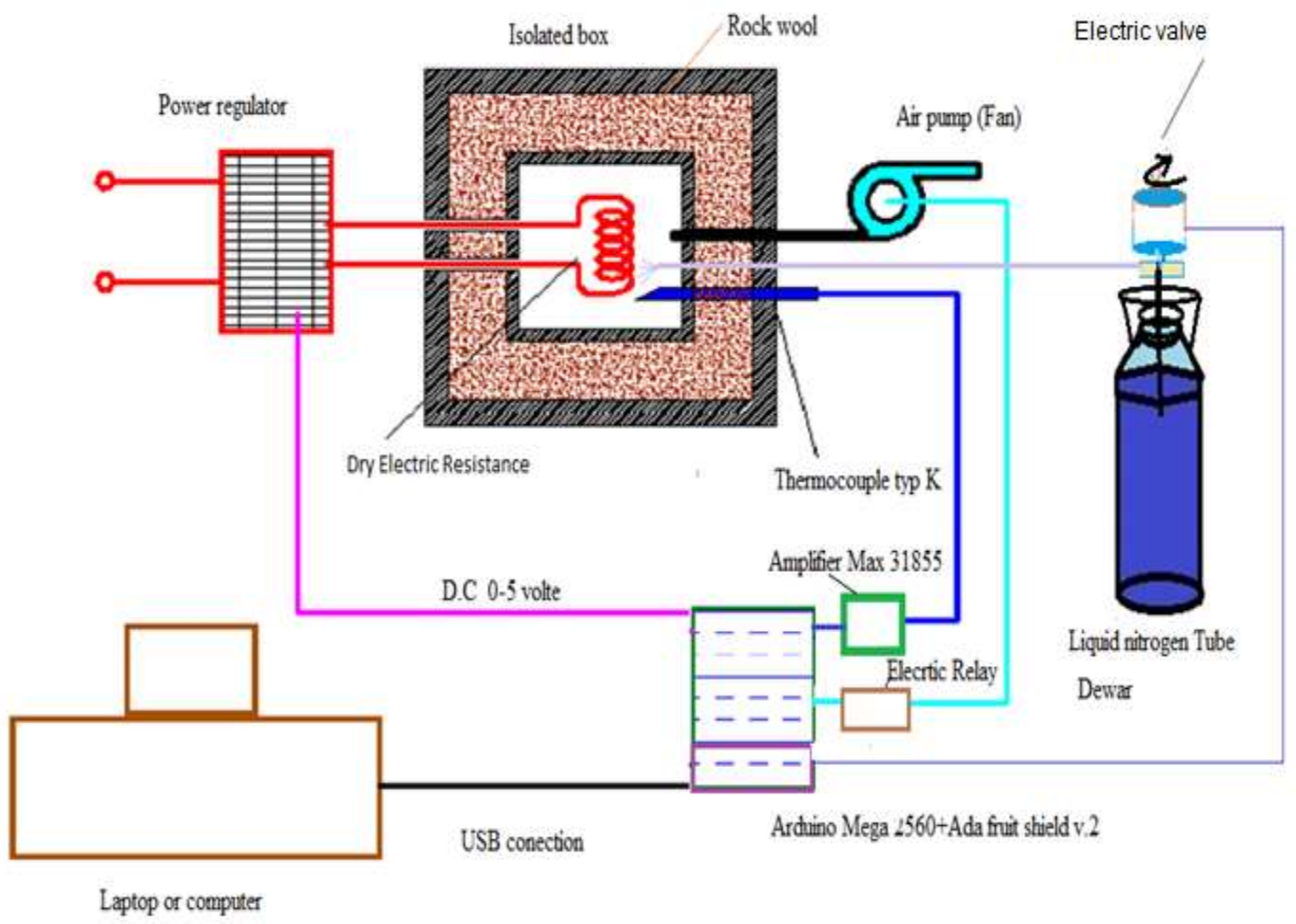

Figure 1. The schematic view of the setup with heating and cooling devices

As stated before, the Arduino card was used as a micro controller in this experimental setup. Arduino card is simple to program, inexpensive, easily available and has many open source codes. Many analog and digital input-output pins such as SPI (Serial Interface) and PWM are available on this card. Arduino has many models with different specifications to be used in several fields. In this study, Arduino Mega 2560 was used. In this feedback system, the temperature of the insulated chamber was measured with K-type thermocouple as the output. K-type thermocouple can produce an analog signal at the micro volt level and can measure temperature between $-180{ }^{\circ} \mathrm{C}$ and $+1300{ }^{\circ} \mathrm{C}$. However, since Arduino can only read voltages at a minimum level of 4.8 milivolt, the Adafruit MAX31855 amplifier, which is compatible with Arduino, has been embedded to the system. This amplifier boosts the micro-volt voltage to the millivolt level as well as converting the analog signal into digital one.

Liquefied gases such as carbon dioxide, nitrogen, neon and helium are used at extremely low temperatures (lower than $-50{ }^{\circ} \mathrm{C}$ ). The most effective cooling process at these low temperatures, also known as cryogenic, is the method with liquid nitrogen whose boiling point is $-195.8^{\circ} \mathrm{C}$ at $1.0 \mathrm{~atm}$. In this study, the liquid nitrogen stored in pressure vessel called Dewar with 50 liters and 1.5 bars was used as refrigerant. The flow of the high pressure liquid nitrogen to the insulated chamber was carried out by a solenoid valve. This electronic valve is either fully opened or closed in totally 12 seconds depending on the applied voltage of $12 \mathrm{~V}$ DC. This solenoid valve from SUN YEH OM-1 model has a ball valve. Adafruit DC motor driver compatible with Arduino was used to control the flow rate of the liquid nitrogen through this valve triggered by PWM on Arduino. During the operations, an air fan with the power of $100 \mathrm{~W}$ actuated by a relay was used in case that the natural cooling speed was not sufficient for natural cooling at high temperatures in the heating zone. In all these processes, the receiving sensor information and transmitting them to the controller on the computer and sending the modified inputsoutputs to the drivers were realized through USB connection with Arduino. The test setup with all hardware is shown in Figure 2. 


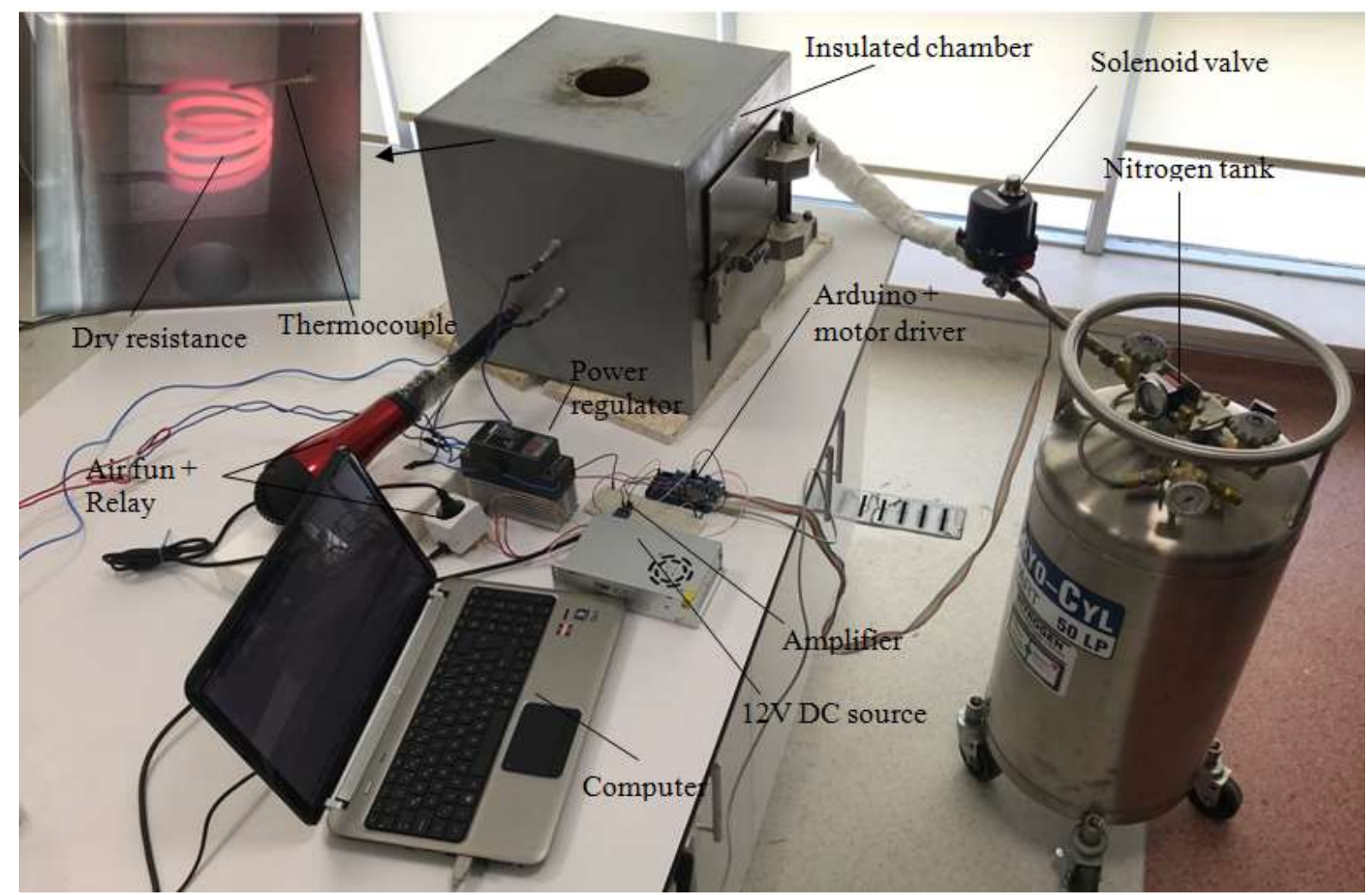

Figure 2. Experimental Setup

\subsection{The System Modeling}

This study is divided into two parts as theoretical and experimental. In the theoretical part, the mathematical model representing both heating and cooling processes was constituted by a first order transfer function with time delay. The temperature response to the step input using this experimental setup was achieved separately for both the heating and the cooling parts. In order to find the parameters of this model, the actual temperature values have been measured and recorded to the step input with a specified input voltage. A graphical method was used to calculate the parameters depending on this recorded data set. More detailed information about this method can be found in literature in [17]. The transfer function between the reference temperature and measured temperature is given in Laplace domain as follows. Here, the initial temperature is considered non-zero.

$$
G(s)=T_{0}+\frac{K}{1+\tau_{2} s} e^{-s \tau_{1}}
$$

$T_{0}$ : Initial temperature

$K$ : Static gain ( $K>0$ for heating and $K<0$ for cooling)

$\tau_{1}:$ Time delay

$\tau_{2}:$ Time constant

The calculated values of the parameters and related models are shown in Table 1. In Figure 3, the graphics with the respective values are given for the transfer function of the model and the experimental results. 
Table 1. The models with corresponding parameters for the thermal system

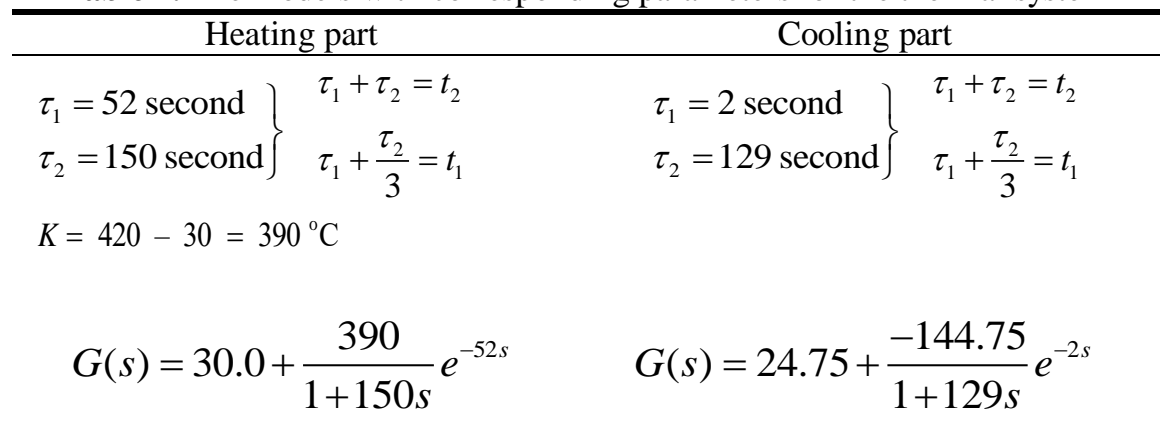

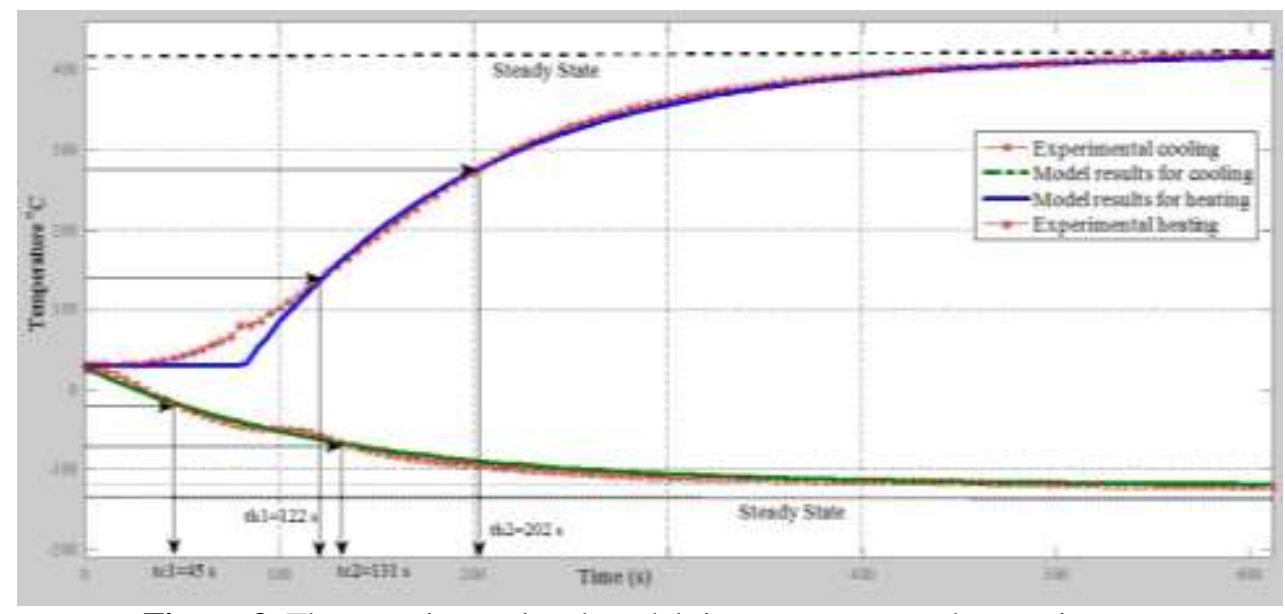

Figure 3. The experimental and model time responses to the step inputs.

As seen in the graph above, unlike the heating part, the delay time in the cooling process is quite smaller. This is because the liquid nitrogen is applied directly into the system and the thermocouple immediately senses the temperature change. In heating, the delay time is quite larger due to the fact that the dry resistance heats itself up first and then increases the temperature of the chamber. In both cases, the responses from the system modeling can suit almost the real time outputs.

\subsection{The Controller Design}

In this study, the control processes are considered as a three-stage action in order to compensate the temperature errors in different phases of heating and cooling. The first part is the control at the heating side and involves the table-supported PID controller used in the region where the temperature is increasing or fixed. In this method, the experiments were fulfilled for a specified input voltage between $0-5 \mathrm{~V}$ by an increment of $0.25 \mathrm{~V}$ and the results were obtained in Figure 4 . The temperature rates corresponding to the input control voltages and the approximate steady state temperatures were tabulated and recorded to be used in the control operations. The intermediate values are defined by interpolation via control software. The PID controller used in the table based method is used for fine tuning. As seen from the graph, the increase in temperature is smaller after the first bending. In fact, the temperature rise after bending should be zero. However, PWM chops AC signals with the amplitude of $220 \mathrm{~V}$ up into discrete portions and switches between $0 \mathrm{~V}$ and $220 \mathrm{~V}$ according to these portions to adjust the nominal voltage, i.e. the average voltage. In other words, although the input voltage is lower or off, the dry resistance continues to consume its full capacity for a while and to raise the temperature. Therefore, we use the PID controller for fine-tuning. 


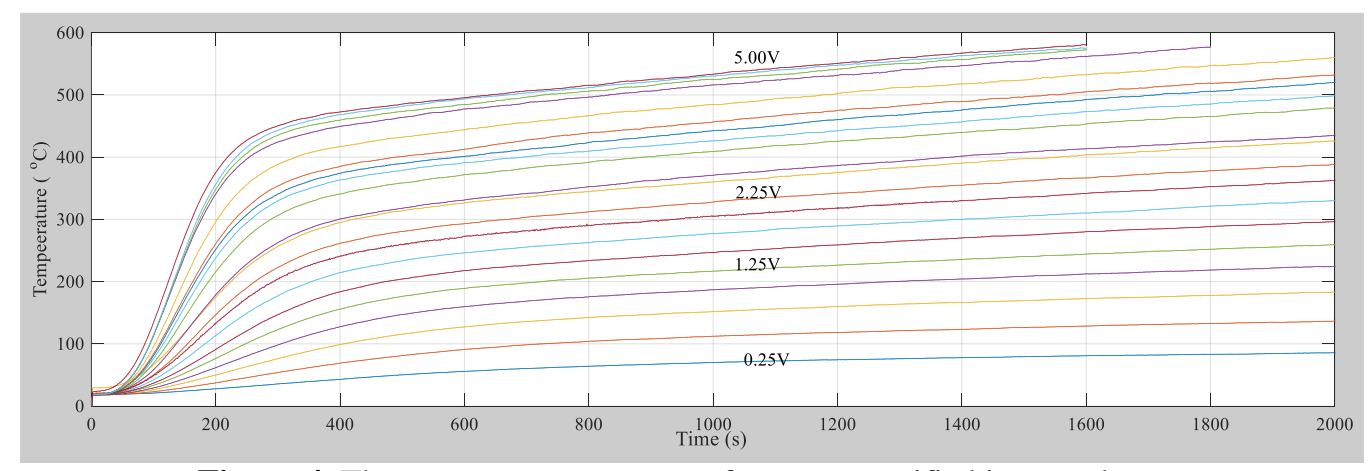

Figure 4. The temperature responses for some specified input voltages

At the second stage, the temperature control involves the shifting from higher temperature to lower one. In this case, the control action used is only PID. However, when switching between these transitions and the natural cooling speed is insufficient, the on-off controlled air fan is activated according to the sign of error. The third stage involves the control phase where the cooling with liquid nitrogen is performed. As soon as the air fan is insufficient to decrease the temperature, the liquid nitrogen is activated in cooling. This stage was accomplished by adjusting the amount of liquid nitrogen via the solenoid valve which received the control signals from Arduino through the motor driver.

The run time on this valve is proportion to the temperature error. So, P controller is used to keep the temperature at the desired one within acceptable limits. If the error is outside these limits, the valve is fully open or completely closed. As a result, during all process, the table supported PID, PID, P and on-off control types were acted as hybrid manner. The basic PID formula is performed for this feedback thermal system as follows.

$u(t)=K_{p} e(t)+K_{i} \int e(t) \mathrm{d} t+K_{d} \frac{\mathrm{d} e(t)}{\mathrm{d} t}$

Here, $u(t)$ is the control input applied on the power regulator or solenoid valve and $e(t)=\mathrm{T}_{\text {Referance }}-\mathrm{T}_{\text {Measured }}$ represents the temperature error. $K_{p}, K_{i}$ and $K_{d}$ are proportional, integral and derivative coefficients of PID respectively.

\section{Experimental Results}

In this study, temperature control experiments addressed for three different situations in order to test the performance of the system. These situations were selected in accordance with the requirements of a tension-compression testing used to determine the stresses that a material is exposed under different temperature conditions. The user-defined temperature profiles for the feedback thermal system were tracked by a program written in MATLAB on a computer with AMD A8-3550mx APU and 8GB RAM. In these experiments, the PID coefficients are defined by trial and error because this thermal system does not provide a marginally stable response to evaluate these coefficients by any method like NicholsZiegler.

In the first experiment, the heating process was only considered. Two step inputs with the temperatures of $+350{ }^{\circ} \mathrm{C}$ and $+250{ }^{\circ} \mathrm{C}$ were chosen as the reference inputs. The temperature behavior changed according to different PID coefficients shown in Figure 5. In this experiment conducted, the table-supported PID control was activated since the input temperatures were fixed. It can be seen that the best results are acquired by PID coefficients of $K_{p}=130, K_{i}=0.04$ ve $K_{d}=30$. 


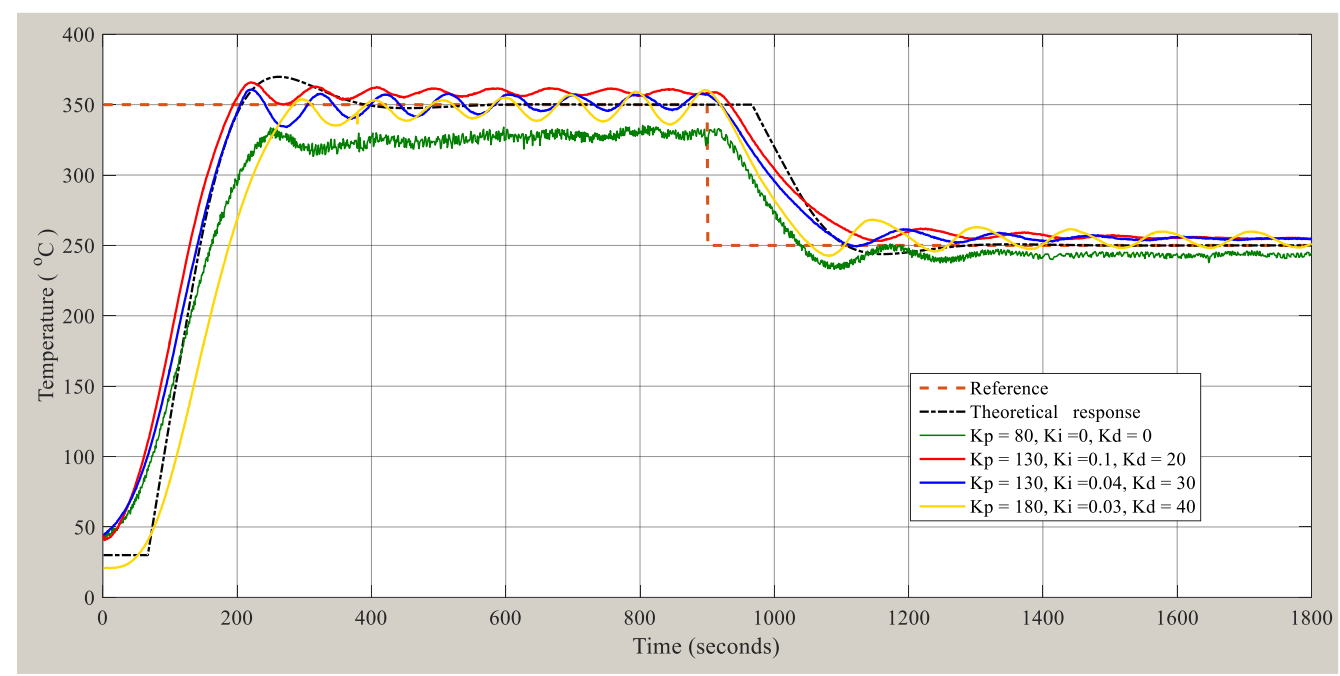

Figure 5. Time responses to the two level step inputs

In another heating experiment, a two-stage ramp input was applied to the system. Here, the temperature was increased up to $+400{ }^{\circ} \mathrm{C}$ in the first 500 s and changing the slop immediately dropped from $400{ }^{\circ} \mathrm{C}$ to $250{ }^{\circ} \mathrm{C}$ in next $400 \mathrm{~s}$. In fact, this experiment was conducted for a process of following a reference. Here, the best follow-up response was obtained for $K_{p}=144, K_{i}=0.7$ and $K_{d}=110$. As can be seen in Figure 6, the integral action plays a very important role to compensate the errors. The proportional control action alone is not sufficient to reach the desired top temperature value. The cooling process in the second region was carried out by the fan-free natural cooling. As can be seen from both graphs, there was a larger time delay due to the nature of thermal systems compared to reference input.

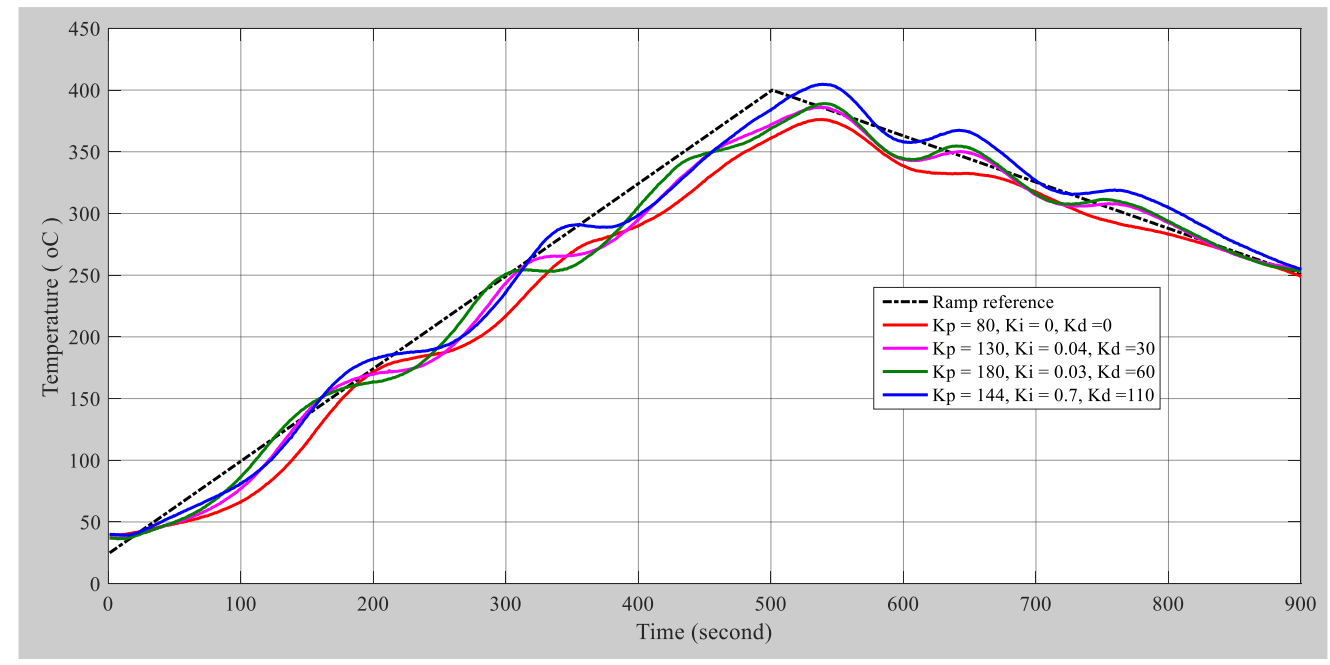

Figure 6. Time responses to the two ramp inputs with different slops

The second type of experimental study was on the cooling of the insulated chamber at room temperature with liquid nitrogen. A user defined reference temperature profile consisting of ramp and step inputs was monitored by opening and closing the solenoid valve by the $\mathrm{P}$ controller. The results are shown in Figure 7. Here, the blue curve was obtained by P control together with an on-off controlled fan whereas the green one was resulted in different conditions which were the nitrogenous pressure 0.5 bars and without air fun assisted. 


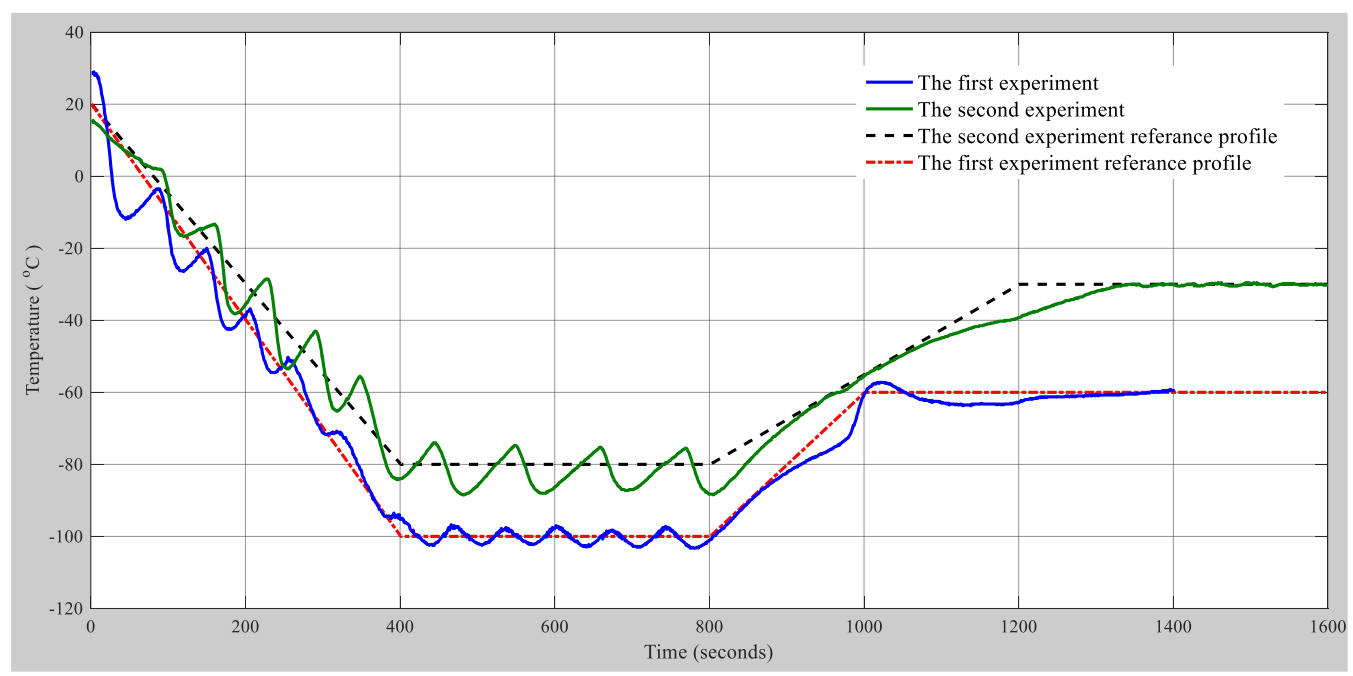

Figure 7. Cooling process for different temperature profiles

Finally, a combination of heating and cooling processes was given in the same cycle seen in Figure 8. This operation, in fact, meets the need of a tensile testing device for full temperature cycle. This experiment was conducted with the constant PID coefficients taken from the previous tests. In this figure, the fluctuations in heating stemmed from the disturbing noise on the thermocouple.

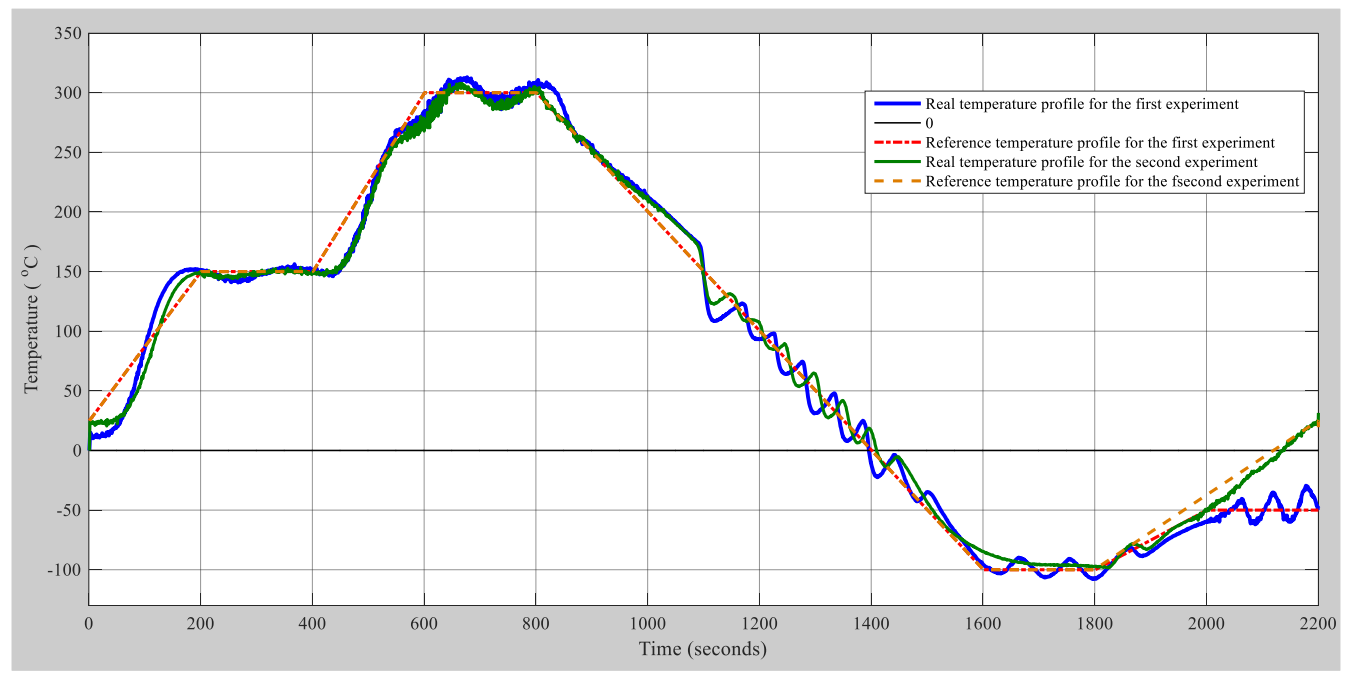

Figure 8. Combined process with temperature control

\section{Discussion and Conclusion}

The determination of the properties of materials in wide range of temperatures is of great importance. The main objective of this study was to design a temperature controlled thermal system with heating and cooling processes used in a tension-compression testing machine. For the cost-effectiveness, compared to other control systems, this experimental setup is relatively inexpensive, easily available and easily programmable in any environment. Especially, the microcontroller of Arduino accomplished the measurement, receiving and transmitting of the related data. The user defined program written in MATLAB has allowed the materials to be tested in different temperature profiles which are a combination of inputs like steps, ramps etc. Considering the results obtained, it is thought that such a system can be preferred in many work areas, especially in cryogenic process.

With this thermal system presented in this paper, the temperature can raise up to $+500{ }^{\circ} \mathrm{C}$ and reduce to $-120^{\circ} \mathrm{C}$. All user defined temperature profiles were also able to be tracked with this feedback system. As seen from the outcomes, the errors compared to the reference inputs are small and acceptable for a tension-compression testing machine. During the experiments, some deviations were observed duo to the disturbances and capability of the devices. The insulated metal box can act as a disturbance since 
it accumulates heat energy and it is trying to increase the temperature in heating or to decrease in cooling even when it is passive. Besides, a solenoid valve was used in the setup. Instead, if a servo valve was used, which provides a flow of nitrogen proportional to the error, more accurate results could be obtained in cooling process. However, the cost of such a valve is quite higher.

The study presented in this paper has provided the following contributions.

- The control system is a relatively simple and inexpensive compared to an equivalent controller such as PLC.

- Considering the manufacturing cost, this thermal system has high performance and can be easily controlled.

- The system operates with very small and reasonable temperature errors with regard to the application field.

In future studies on this subject, instead of PID controller, more modern controllers such as sliding mode controller, fuzzy-logic controller can be used for more accurate results.

\section{Acknowledgment}

This paper is originated from the master thesis with the name of "Temperature Control of a System with Small Volume in Heating and Cooling Process" prepared by Sulaiman Abdullah Mohammed at Van Yuzuncu Yil University, Institute of Natural and Applied Sciences, Van/Turkey. The study was supported Van Yuzuncu Yil University, BAP, project number: 2015-FBE-YL305 as well as TÜBİTAK, project number: $215 \mathrm{M} 808$.

\section{References}

[1] Turunen T. 2006. Electrical Floor Heating Systems in China Shenyang Jianzhu. University Tampere Polytechnic, Bachelor's Thesis, 44s, China.

[2] Wu D.W., Wang R. 2006. Combined Cooling Heating and Power: A Review. Progress in Energy and Combustion Science, 32 (5-6): 459-495.

[3] Agrawal P.C. 1989. A Review of Passive Systems for Natural Heating and Cooling of Buildings. Solar \& Wind Technology, 6 (5): 557-567.

[4] Haye E. 2013. Industrial Solutions for Inductive Heating of Steels. Uleå University of Technology Department of Engineering Sciences and Mathematics,114s, Master Thesis. Sweden.

[5] Ryckaert V.G., Claes J.E., Van Impe J.F. 1999. Model-Based Temperature Control in Ovens. Journal of Food Engineering, 39 (1): 47-58.

[6] Srisertpol J., Supot P. 2010. Model Reference Adaptive Temperature Control of The Electromagnetic Oven Process in Manufacturing Process. Proceedings of the 9th WSEAS International Conference on Signal Processing, Robotics and Automation. World Scientific and Engineering Academy and Society (WSEAS). pp: 57-61.

[7] Dhananchezian M., Pradeep K. 2010. Experimental Investigation of Cryogenic Cooling by Liquid Nitrogen in the Orthogonal Machining of Aluminum 6061-T6 Alloy. International Journal of Machining and Machinability of Materials, 7(3-4): 274-285.

[8] Lizon J. 2010. Liquid Nitrogen Pre-cooling of Large Infrared Instrument at ESO, SPIE Astronomical Telescopes and Instrumentation, International Society for Optics and Photonics, 77393F-77393F.

[9] Schoeman R. 2012. Design and Development of an Automated Temperature Controller for Curing Ovens, Vaal University of Technology, Electronic Engineering. Master Thesis, Vanderbijlpark, 102s, South Africa.

[10] Appelblad A. 2014. Development of a Temperature Controlled Cell for Surface Enhanced Raman Spectroscopy for in Situ Detection of Gases. Umeå University Department of Physics, Master Thesis, 53s, Sweden.

[11] Lute P., Dolf V. 1995. Optimal Indoor Temperature Control Using a Predictor. IEEE Control Systems, 15 (4): 4-10.

[12] Jiang W., Xuchu J. 2012. Design of an Intelligent Temperature Control System Based on the Fuzzy Self-tuning PID. International Symposium on Safety Science and Engineering in China, (ISSSE), 43: 307-311. 
[13] Ding S., Wenhui Li. 2013. Temperature Monitoring System Based on PLC. International Journal Electrical Engineering and Computer Science, 11 (12): 7251-7258.

[14] Bolat E. 2007. Real Time Temperature Control of Oven Using Matlab-SIMULINK. Proceedings of the 11th WSEAS International Conference on Systems, Agios Nikolaos, Crete Island, Greece, pp: 424-429.

[15] Krishnamurthi K., Thapa S., Kothari L., Prakash A. 2015. Arduino Based Weather Monitoring System. International Journal of Engineering Research and General Science, 3(2): 452-458.

[16] Ayuba Y. 2016. Temperature Control and Data Acquisition Method for Factory Using LabVIEW. International Journal of Computer Engineering \& Technology (IJCET), 7 (2): 1-14.

[17] Zareh S., Kambiz O. 2009. The Design of PID Controller for a Thermal System with Large TimeDelay. International Journal of Mechanical, Aerospace, Industrial, Mechatronic and Manufacturing Engineering, 3 (8): 1023-1027. 